\title{
RESISTENSI KEPIK COKLAT (Riptortus linearis) TERHADAP JENIS INSEKTISIDA BRANTAS 25 EC PADA TANAMAN KACANG PANJANG
}

\author{
Oky Magdalena Bunga ${ }^{1}$, Yonce M. Killa², Suryani K.K.L Kapoe ${ }^{3}$ \\ 1,2,3 Program Studi Agroteknologi Fakultas Sains Dan Teknologi Universitas Kristen Wira Wacana Sumba \\ Jl. R.Suprapto.35 Waingapu \\ Email: magdalenabunga9@gmail.com (korespondensi)
}

\begin{abstract}
Brown ladybug (R. linearis) is the main pes on long bean planst, there is also a way ( $\mathrm{R}$. linearis) piercing the stylet into the pods and seeds, so that the pods and seeds of the long bean can fall of and the seeds wrinle, the population of ( $\mathrm{R}$. linearis) at all stages can potentially damage long bean pods, for that farmers take chemical control measures, namely by using chemical insecticide sprays to control pests, but in ineffective control, pest resistsnce can occur, resulting in failure in control, otherwise it may undergo residue and resurgensi. Currently there is no data regarding the evaluation of resistance of the pes (R.linearis) to the use of chemical insecticides in the district of East Sumba. Therefore, it is necessary to conduct research on the resistance test of ( $\mathrm{R}$. linearis) to the chemical insecticide Brantas $25 \mathrm{EC}$ in the laboratory. The results showed that the application of chemical insecticides Brantas $25 \mathrm{EC}$, at (R. linearis) with a concentration of 0,25 $\mathrm{ml} / \mathrm{l}$, $0,5 \mathrm{ml} / \mathrm{l}, 0,75 \mathrm{ml} / \mathrm{l}, 1,00 \mathrm{ml} / \mathrm{l}$ dan $1,25 \mathrm{ml} / \mathrm{l}$ can be seen mortality within 24 hours resulting in the highest mortality of $66 \%$. The results of the estimated resistance ratio showed that the application of chemical insecticides against (R.linearis) with LC50, could result in the highest resistance, which was 3,44\%. The observations were carried out 28 hours after the application of chemical insecticides Brantas 25 EC.
\end{abstract}

Keywords: Riptortus linearis, Vigna unguiculata, brantas 25 EC

\begin{abstract}
Abstrak
Kepik coklat (Riptortus linearis) merupakan hama utama pada tanaman kacang panjang, adapun cara hama R. linearis merusak tanaman kacang panjang dengan cara R. linearis menusuk stiletnya ke dalam polong dan biji, sehingga polong dan biji kacang panjang dapat gugur dan biji keriput. Populasi hama R. linearis pada semua stadium, dapat berpotensi merusak polong kacang panjang, untuk itu para petani melakukan tindakan pengendalian secara kimia yaitu dengan menggunakan penyemprotan insektisida kimia untuk mengendalikan hama, namun dalam pengendalian yang tidak efektif dapat mengalami resistensi hama, sehingga terjadinya kegagalan dalam pengendalian, selain itu dapat mengalami residu dan resurjensi. Saat ini belum terdapat data, terkait evaluasi resistensi hama R. linearis terhadap penggunaan insektisida kimia di Kabupaten Sumba Timur. Oleh karena itu, perlu di lakukan penelitian tentang uji resistensi hama $\mathrm{R}$. linearis terhadap insektisida kimia (Brantas 25 EC) di laboratorium. Hasil penelitian meenunjukan bahwa aplikasih insektisida kimia brantas 25 EC, pada hama R. linearis dengan konsentrasi 0,25 $\mathrm{ml} / \mathrm{l}, 0,5 \mathrm{ml} / \mathrm{l}, 0,75 \mathrm{ml} / \mathrm{l}, 1,00 \mathrm{ml} / \mathrm{l}$ dan 1,25ml/l dapat di lihat mortalitas R. linearis dalam waktu 24 jam, dengan mengakibatkan mortalitas tertinggi 66\%. Hasil penelitian Estimated resistance ratio (ERR), menunjukan bahwa aplikasih insektisida kimia terhadap R.linearis dengan LC50, dapat mengakibatkan resistensi tertinggi yaitu 3,44\% pengamatan dilakukan 28 jam setelah aplikasih insektisida kimia brantas 25 EC.
\end{abstract}

Kata kunci:Kepik coklat, kacang panjang, brantas 25 EC 


\section{Pendahuluan}

Kacang panjang adalah salah satu jenis sayuran di Indonesia maupun di dunia yang berasal dari India dan Cina. Tanaman kacang panjang memiliki kandungan vitamin, serat tinggi, serta mineral yang berfungsi dalam metabolisme tubuh yang berguna untuk meningkat kecerdasan, ketahanan tubuh dan memperlancar proses pencernaan di dalam tubuh manusia (Zeavie, 2014). Tanaman kacang panjang banyak mengandung vitamin $A, B$, dan $C$, terlebih pada polong muda. Biji kacang panjang mengandung karbohidrat, lemak dan protein. Selain untuk di jadikan sayur, tanaman kacang panjang juga dapat menyuburkan tanah, karena pada akar memiliki bintil-bintil akar sehingga dapat menangkap nitogen bebas dari udara. (Selvia dkk 2015).

Usaha budidaya tanaman kacang panjang, banyak kendala salah satunya adalah permasalahan hama dan penyakit (Capiner, 2001). Serangga merupakan hama (Pest) di bidang pertanian, yang bersifat merusak tanaman dan merugikan petani. Selain itu, sebagai vektor penyakit yang berupa virus atau jamur pada tanaman. Sebagian spesies serangga juga bersifat menguntungkan bagi petani, yaitu sebagai parasitoid, predator, atau musuh alami. Serangga yang berperan baik pada tanaman disebut Helpful or beneficial insect. Serangga memiliki cara hidup yang beragam yaitu, hidup dipermukaan tanaman, juga hidup di dalam jaringan tanaman dengan cara mengorek, mengorok atau membentuk paru. Selain itu ada yang hidup didalam tanah seperti perakaran. Serangga sebagai fitofag dapat memakan bagian-bagian dari tanaman yaitu mulai dari akar, batang, daun, bunga dan buah. (Meilin \& Nasamsir, 2016).

Hama kepik coklat ( $R$. linearis) merupakan salah satu serangga dan hama utama pada tanaman kacang panjang. Ciri khas hama tersebut adalah pada imago terdapat duri di paha belakang dan garis putih kekuningan dibagian lateral tubuhnya (Arifin dkk., 2010). Adapun gejala yang di timbulkan akibat serangan hama ( $R$. linearis) adalah polong gugur dan biji keriput. Hama kepik coklat (R. linearis) pada stadia imago merusak tanaman kacang panjang dengan cara, menusuk stilet kedalam kulit polong hingga kebiji dan mengisap cairan biji kacang panjang, persentase kerusakan akibat imago $R$. linearis adalah 80\% (Marwoto, 2006).
Populasi $R$. linearis mempengaruhi tingkat kerusakan, pada polong dan terdapat 3 ekor/5 tanaman pada nilai ambang ekonomi $R$. linearis, dengan umur tanaman 45 hari. Kerugian dari satu ekor R. linearis di satu tanaman dapat menimbulkan keusakan pada polong adalah $49 \%$ dari luasan 798 ha dengan intensitas serangan adalah17,82\% Direktorat Bina Perlindungan tanaman (1999). Kerugian tanaman kacang panjang juga terdapat di Propinsi Sumatra Utara pada tahun 2013 adalah 32,61R

Pada umumnya, insektisida kimia merupakan salah satu pilihan utama bagi petani, untuk mengendalikan hama pada tanamannya (Bayu, 2017). Salah satu cara untuk mengendalikan hama $\mathrm{R}$. linearis pada tanaman kacang panjang, yaitu menggunakan insektisida kimia Brantas 25 EC. Dampak penggunaan insektisida kimia antara lain dapat menyebabkan resurjensi serangga (Ratna dkk., 2009). Penggunaan insektisida kimia dapat mengakibatkan terjadinya kerusakan ekosistem dan resistensi hama. Puspitasari dan Marendra (2016). Selanjutnya, dampak penggunaan insektisida kimia mengalami residu terhadap hasil pertanian dan pakan hewan (rumput), yang sudah terpapar oleh pestisida. Residu juga terakumulasi di bagian lapisan atas tanah sehingga bisa mengakibatkan berkurangnya populasi mikroba heterotropik dan kelompok bakteri nitrifikasi pada tanah. (Sulistinah dkk., 2011). Residu tersebut dapat menimbulkan efek secara tidak langsung terhadap manusia pada jangka waktu yang panjang. Selain itu, dampak lainnya dapat menyebabkan gangguan kesehatan pada syaraf maupun metabolisme enzim (Yusnani, 2013).

Usaha pengendalian hama yang di lakukan petani masih menggunakan insektisida kimia yang efektif, praktis serta mengurangi biaya produksi. Salah satu alternatif pengendalian berdasarkan, konsep PHT (Pengendalian Hama Terpadu) yaitu, dengan cara mengendalikan hama $R$. linearis menggunakan pestisida nabati yang relatif aman bagi lingkungan. dan juga cepat terurai sehingga, tidak menjadi bahan berbahaya. Saat ini belum terdapat data, terkait evaluasi resistensi hama $R$. linearis terhadap beberapa penggunaan insektisida kimia di Kabupaten Sumba Timur. Oleh karena itu, perlu di lakukan penelitian tentang $u j i$ resistensi hama $R$. linearis terhadap insektisida kimia (Brantas 25 EC) di laboratorium. 


\section{TINJAUAN PUSTAKA}

\subsection{Klasifikasi dan bioekologi Riptortus linearis}

Klasifikasi $R$. Linearis menurut Wahyu (2010), adalah: Kingdom: Animalia Filum, Arthropoda Kelas : Insecta, Ordo: Hemiptera, Famili: Alydidae, Genus: Riptortus, Spesies: Riptortus linearis.

Kepik polong kacang panjang $(R$ linearis) memiliki metamorfosis paurometabola yaitu terdiridari telur, nimfa, dan imago. Telur $R$ linearis berbentuk bulat dan berwarna cokelat. Hama $R$. linearis memiliki lama stadia telur sampai menetas sekitar 6,37 $\pm 0,82$ hari. Hama $R$. linearis memiliki VI instar, yaitu instar pertama mirip semut gramang, berwarna kuning-kuningan dan aktif bergerak mencari makan. Selanjutnya stadium instar satu berlangsung selama 1-3 hari (Prayogo dan Suharsono, 2005). Instar ke II mirip semut gramang,berwarna coklat kekuningandan aktif bergerak mencari makan,rata-rata lama stadium instar II yaitu 4,75 $\pm 1,61$ hari. Instar ke III berbentuk semut gramang berwarna cokelat, dan aktif bergerak namun tidak seaktif instar I dan II. Nimfa instar IV mirip semut hitam,namun tidak seaktif instar I dan II, Stadium instar IV dapat berlansung 4,54 $\pm 2,27$ hari. Instar ke $V$ berwarna hitam ke abu-abuan,mirip semut hitam lama stadium instar $V$ berlangsung $6,20 \pm 1,58$ hari. Pada beberapa hama dapat memiliki hingga instar VI dengan bentuk seperti nimfa instar $V$, dan lama stadium $6,67 \pm 1,12$ hari. Berdasarkan hal tersebut, kondisi lingkungan dan kualitas makanan berpengaruh terhadap jumlah instar pada hama. HamaR. linearis memiliki tubuh memanjang, berwarna kuning coklat dan memiliki sayap. Perbedaan antara imago jantan dan imago betina dapat diketahui dari bagian abdomen. Abdomen betina memiliki garis segitiga berwarna putih. Pada saat betina sudah memiliki telur, abdomen membesar dan mengembung di bagian tengah. Abdomen jantan memiliki garis memanjang berwarna putih dan juga abdomen lurus ke belakang. Rata-rata lama stadium imago yaitu : 29,3 $\pm 13,75$ hari dan lamaperkembangan $R$. linearis dari telur sampai imago adalah 64,48 hari (Mawan dan Herma 2011).

\subsection{Gejala serangan $R$.linearis}

\section{Hama kepik coklat}

(R.linearis) merupakan hama yang dapat menyerang tanaman kacang-kacangan, terutama tanaman kacang panjang. Kerugian akibat serangan hama kepik coklat dapat mencapai
80\% (Tengkano dkk., 2006).Hama R.linearis dapat menyebabkan kerusakan polong kacang panjang, yaitu dengan cara $R$. linearis mengisap cairan biji dalam polong, dengan menusuk stilet ke kulit polong. Nimfa dan imago memiliki kemampuan yang sama, yang mengakibatkan kerusakan pada polong kacang panjang (Prayogono dan Suharsono., 2005). Selain dapat mengisap polong, adapun kerugian yang cukup tinggi, R.linearisdapat mengeluarkan embun madu, yang menjadi media tumbuh cendawan jelaga dan menutupi permukaan daun sehingga proses fotosintesis tidak dapat berjalan dengan baik (Inani, 2006).

\subsection{Insektisida Brantas 25 EC}

Insektisida Brantas 25EC tergolong dalam bahan aktif Lamda sihalotrin. Bahan aktif Lamda Sihalotrin merupakan bahan aktif insektisida yang sudah terdaftar di Indonesia. Pada Insektisida Brantas 25EC mengandung bahan aktif Lamda Sihalotrin $25 \mathrm{~g} / \mathrm{L}$,formulasi nilai LD 50, dengan nama merek dagang Brantas 25 EC, dalam kemasan botol $50 \mathrm{ml}, 100 \mathrm{ml}, 200 \mathrm{ml}$, dan $500 \mathrm{ml}$, dengan warna larutan kuning, jenis berat 449,9, $\mathrm{PH} 5.4$, tekanan uap $100^{\circ} \mathrm{C}$, berat molekul NA, yang merupakan racun kontak dan lambung yang bersifat non sistemik, berbentuk pekatan yang dapat mengendalikan berbagai jenis serangga seperti kumbang, trips, lepidoptera dan coleoptera (Direktorat Jendral Prasarana dan sarana pertanian, 2016).

\subsection{Dampak Insektisida Kimia Terhadap R.linearis}

Dampak insektisida kimia terhadap $R$. Linearis yaitu mampu membunuh pada stadia nimfa dan imago, namun pada stadia telur tidak dapat merusak, tetapi dapat bertahan dan berkembang menjadi stadia lanjut. Pengendalian $R$. linearis menggunakan insektisida kimia kurang berhasil, sehingga keberadaan hama berkembang secara terus menerus di lapangan. Oleh karena itu, pengendalian $R$. linearis dengan menggunakan insektisida kimia menjadi kurang berhasil (Prayogo, 2009). Selain itu, dampak penyemprotan insektisida kimia pada hama $R$. linearis, dapat mengenai tanaman kacang panjang juga pada polong. Ketika $R$. linearis menusuk stilet ke dalam polong kacang panjang, $R$. linearis dapat terbunuh atau mati. Insektisida memiliki kandungan racun klorpirifos yang lebih persisten, dan cara klorpirifos itu sebagai racun kontak lambung dan pernapasan (Venugopal dkk., 2012). Klorpirifos merupakan insektisida 
organofosfat, yang berupa kristal beracun dan paparan kronis dapat dikaitkan dengan efek neurologis, gangguan perkembangan dan gangguan autoimun dapat membunuh larva. Selain itu, insektisida sintetis dari golongan Buprofezin sebagai racun syaraf pada serangga. Pengaplikasian insektisida klorpirifos dengan dosis $3 \mathrm{ml} / \mathrm{l}$ merupakan metode yang efektif dalam pengendalian serangga, yaitu dengan menurunya populasi serangan hama (Zote dkk. 2017).

\section{METODOLOGI PENELITIAN}

\subsection{Waktu dan Tempat}

Penelitian akan dilaksanakan di Laboratorium Terpadu, Fakultas Sains dan Teknologi Universitas Kristen Wira Wacana Sumba, selama 4 bulan dimulai dari Juni sampai Desember 2021

\subsection{Alat dan Bahan}

Alat yang digunakan dalam penelitian ini adalah stoples plastik, jaring, kain kasa, karet gelang, tisu, kapas, sarung tangan, masker, alat tulis, kamera, sedangkan bahan yang digunakan adalah kacang panjang, madu, insektisida ( Brantas $25 \mathrm{EC}$; Produk Nufram Indonesia), serangga $R$. linearis instar 3.

\subsection{Rancangan Penelitian}

Penelitian ini dilakukan di Laboratorium dengan menggunakan Rancangan Acak Lengkap (RAL) terdiri atas 6 perlakuan dan 3 ulangan. Serangga yang akan diuji menggunakan adalah serangga nimfa $\mathrm{R}$. linearis instar ketiga. Setiap perlakuan diulang sebanyak 3 kali. Konsentrasi yang ditentukan berdasarkan uji pendahuluan yaitu:

A: Tanpa insektisida (Kontrol) $0 \mathrm{ml} / \mathrm{L}$,

B: Insektisida dengan konsentrasi $0,25 \mathrm{ml} / \mathrm{L}$, C: Insektisida dengan konsentrasi $0,5 \mathrm{ml} / \mathrm{L}$, $\mathrm{D}$ : Insektisida dengan konsentrasi 0,75 $\mathrm{ml} / \mathrm{L}$,

$\mathrm{E}$ : Insektisida dengan konsentrasi $1,00 \mathrm{ml} / \mathrm{L}$, $\mathrm{F}$ : insektisida dengan konsentrasi $1,25 \mathrm{ml} / \mathrm{L}$.

Data yang hasil penelitian dianalisis dengan sidik ragam analysis of variance (ANOVA). Jika terdapat perlakuan yang berbeda nyata maka dilakukan uji lanjut menggunakan DMRT (Duncan's Multiple Range Test) pada taraf 5\%.

\subsection{Pelaksanaan Penelitian}

Pelaksanaan penelitian $u j i$ resistensi kepik coklat $(R$. linearis ) pada tanaman kacang panjang terhadap jenis insektisida kimia Brantas 25 EC di Laboratorium melalui empat tahap, sebagai berikut :

a. Perbanyakan $R$. linearis

Pada proses perbanyakan serangga digunakan imago betina $R$. linearis yang berasal dari lahan pertanaman kacang panjang yang berlokasi di desa Maulumbi. Pada perbanyakan ini, serangga tersebut ditempatkan dalam stoples plastik yang berukuran dengan diameter $16 \mathrm{~cm}$ dan tinggi $17 \mathrm{~cm}$ lalu bagian atas stoples tersebut ditutup dengan kain kasa. Selanjutnya, agar serangga dapat meletakan telur maka diletakkan kapas sebagai tempat peletakan telur. Pergantian pakan dan kain kasa dilakukan setiap 2 (dua) hari sekali. Jika kapas tersebut telah dipenuhi telur $R$. linearis maka kapas wajib diganti dengan kapas yang baru. Selanjutnya kapas yang telah berisi telur ditempatkan pada stoples yang baru agar telur dapat menetas menjadi nimfa.

Pakan yang digunakan adalah pakan dalam keadaan masih muda dan segar yang diperoleh dari pasar Matawai Sumba Timur. Pemberian pakan pada imago $R$. linearis dilakukan dengan cara memotong kacang panjang dengan ukuran $5 \mathrm{~cm}$. Sebanyak 15 potong kacang panjang dimasukkan ke dalam stoples plastik sebagai pakan $R$. linearis. Setiap stoples berisi 50 individu imago $R$. linearis. Metode perbanyakan R. linearis ini mengacu pada metode yang dilakukan oleh Amalia dkk. (2017).

b. Persiapan Serangga Uji

Serangga uji yang digunakan adalah serangga yang berasal dari populasi di laboratorium yang sudah diperbanyak hingga generasi pertama (F1) dan tidak pernah terpapar insektisida. Serangga uji yang digunakan adalah nimfa $R$. linearis instar ketiga.

\section{c. Persiapan Insektisida}

Insektisida yang digunakan adalah insektisida kimia dengan merek dagang Brantas 25 EC, dengan bahan aktif lamba sihalotrin insektisida diperoleh dari toko pertanian dan bersifat tidak kadaluarsa.

\section{d. Uji resistensi nimfa $R$. linearis}

Uji resistensi dapat dilakukan dengan cara polong kacang panjang yang berukuran $6 \mathrm{~cm}$ dicelupkan ke dalam larutan insektisida selama 10 detik. Selanjutnya polong kacang panjang yang telah dicelupkan, ditiriskan pada kertas koran setelah larutan kering, dipindahkan kedalam masing-masing stoples plastik kemudian di masukan 1 potong potong kacang panjang dan masukan 20 ekor nimfa $R$. linearis instar ke tiga, pada tingkat resistensi dapat dilakukan dengan 
cara diuji sebanyak 6 (enam) perlakuan dan 3 (tiga) ulangan.

\subsection{Variable Pengamatan}

1. Pengamatan Mortalitas Mortalitas Nimfa $=\frac{\sum \text { Nimfa yang mati }}{\sum \text { Nimfa seluruhnya }} \times 100 \%$

2. Pengamatan Estimated resistance ratio (ERR)

$$
\mathrm{ERR}=\frac{\text { LC50 Nimfa Uji }}{\text { LC50 Nimfa Kelompok Kontrol Positif }}
$$

\section{HASIL DAN PEMBAHASAN}

\subsection{Mortalitas serangga R.linearis}

Dari hasil penelitian pengaruh insektisida kimia Brantas 25 EC terhadap motralitas $R$. linearis, dapat dilakukan pengamatan setelah aplikasi dalam waktu 24 jam Prsentasi mortalitas tertinggi $66,6 \%$ dan terendah $0 \%$ terdapat pada perlakuan $\mathrm{F}$ dan A tingginya mortalitas $R$ linearis disebabkan oleh tingginya konsentrasi yang diberikan sehingga mortalitas semakin tinggi. Hasil analisis sidik ragam, menunjukan bahwa berpengaruh nyata terhadap presentasi mortalitas Nimfa $R$.linearis, yang telah dilakukan pengujian dengan konsentrasi $A$ control (0), B. 0,25 ml/l, C. 0,5 ml/l, D. 0,75 $\mathrm{ml} / \mathrm{l}$, dan F. 1,25 ml/l menunjukan ada pengaruh nyata dari tiap-tiap perlakuan. Hal ini di lihat dari table bahwa konsentrasi $B$. $0,25 \mathrm{ml} / \mathrm{l}$, berbeda nyata dengan konsentrasi C. $0,5 \mathrm{ml} / \mathrm{l}$ dan juga pada konsentrasi $\mathrm{D}$. $0,75 \mathrm{ml} / \mathrm{l}$ berbedanyata dengan $\mathrm{E} .1,00 \mathrm{ml} / \mathrm{I}$ dan pada konsentrasi F. 1,25 ml/l berbeda nyata dengan konsentrasi B, C, D, E. Pada perlakuan $A$ (control) berbeda sangat nyata dengan B, C, D, E, dan F. Sejalan dengan penelitian Atmadja dkk., (2009), menunjukan tingginya mortalitas hama pengisap buah terhadap insektisida Lamda Sihalotrin 25 EC, dengan ketinggian mortalitas hama pengisap buah yaitu 67 $100 \%$.

Tabel 1. Persentase Mortalitas R. Linearis

\begin{tabular}{|c|c|}
\hline Perlakuan & Mortalitas (\%) \\
\hline Kontrol & $0 \mathrm{a}$ \\
\hline $0,25 \mathrm{ml} / \mathrm{l}$ & $23,3 \mathrm{a}$ \\
\hline $0,5 \mathrm{ml} / \mathrm{l}$ & $20 \mathrm{~b}$ \\
\hline $0,75 \mathrm{ml} / \mathrm{l}$ & $30 \mathrm{~b}$ \\
\hline $1,00 \mathrm{ml} / \mathrm{l}$ & $13 \mathrm{a}$ \\
\hline $1,25 \mathrm{ml} / \mathrm{l}$ & $66,6 \mathrm{c}$ \\
\hline
\end{tabular}

Ket. Angka yang di ikuti huruf yang tidak sama pada kolom yang sama menunjukan beda nyata pada taraf $5 \%$ menurut Duncan multiple range test (DMRT).

\subsection{Estimated resistance ratio (ERR)}

Hasil penelitian resistensi hama $\mathrm{R}$ linearis terhadap insektisida brantas $25 \mathrm{EC}$, dapat di lakukan pengamatan selama 24 jam setelah diaplikasi insektisida, dengan sejumlah 10 ekor per perlakuan, dari 6 perlakuan terdapat pada perlakuan $\mathrm{F}$ mengalami resistensi 3,44\% yaitu terdapat pada table 2. Hasil estimated resistance ratio (ERR) dapat diketahui berdasarkan hasil sidik ragam menunjukan bahwa, beberapa konsentrasi insektisida Brantas 25 EC, berpengaruh nyata terhadap uji resistensi hama $R$. linearis, pada setiap perlakuan yang telah dilakukan pengujian dengan konsentrasi A (control), B. 0,25ml/l, C. 0,5 $\mathrm{ml} / \mathrm{l}$, D. $1,25 \mathrm{ml} / \mathrm{l}$, E. $1,00 \mathrm{ml} / \mathrm{l}$ dan $\mathrm{F}$. $1,25 \mathrm{ml} / \mathrm{l}$, menunjukan hasil resistensi hama $R$. linearis dengan menggunakan insektisida brantas $25 \mathrm{EC}$, terdapat pada perlakuan A (control) dan F.1,25ml/l sangat berpengaruh nyata dengan perlakuan B. $0,25 \mathrm{ml} / \mathrm{I}, \mathrm{C} .0,5$ $\mathrm{ml} / \mathrm{l}, \mathrm{D} .0,75 \mathrm{ml} / \mathrm{l}, \mathrm{E}, 1,00 \mathrm{ml} / \mathrm{l}$. Penelitian lain juga menunjukan penggunaan bahan kimia Lamda sihalotrin dapat mengakibatkan resistensi pada wereng coklat dengan nilai RR 3,5\% menurut (Baehaki, 2016).

Tabel 1. Rata-rata estimated Resistance Rasio (ERR)

\begin{tabular}{|c|c|}
\hline Perlakuan & $\begin{array}{r}\text { Rata-rata estimated } \\
\text { Resistance Rasio (ERR) }\end{array}$ \\
\hline A.Kontrol & $1,00 \pm 0,000 \mathrm{a}$ \\
\hline B. $0,25 \mathrm{ml} / \mathrm{l}$ & $1,34 \pm 0,291 \mathrm{a}$ \\
\hline C. $0,5 \mathrm{ml} / \mathrm{l}$ & $1,25 \pm 0,000 \mathrm{a}$ \\
\hline D. $0,75 \mathrm{ml} / \mathrm{l}$ & $1,43 \pm 0,000 \mathrm{a}$ \\
\hline E. $1,00 \mathrm{ml} / \mathrm{l}$ & $1,15 \pm 0,080 \mathrm{a}$ \\
\hline F.1,25 ml/l & $3,44 \pm 1,503 \mathrm{~b}$ \\
\hline
\end{tabular}

Ket. Angka yang di ikuti huruf yang tidak sama pada kolom yang sama menunjukan beda nyata pada taraf $5 \%$ menurut Duncan multiple range test (DMRT).

\section{KESIMPULAN DAN SARAN}

Hasil penelitian dapat di simpulkan bahwa aplikasi insektisida kimia brantas 25 EC pada serangga $R$. linearis dengan konsentrasi A (control), B. 0,25ml/l, C. 0,5 $\mathrm{ml} / \mathrm{l}$, D. $1,25 \mathrm{ml} / \mathrm{l}$, E. $1,00 \mathrm{ml} / \mathrm{l}$ dan $\mathrm{F}$. $1,25 \mathrm{ml} / \mathrm{l}$, dapat mengakibatkan mortalitas tertinggi $66 \%$. Hasil aplikasi insektisida kimia brantas 25 EC tehadap serangga R. linearis yang berasal dari populasi laboratorium, yang sudah di perbanyak hingga generasi pertama (F1) dengan konsentrasi, A.control, B. 0,25 ml/l, C. 0,5 
$\mathrm{ml} / \mathrm{l}$, D. 0,75 ml/l, E. $1,00 \mathrm{ml} / \mathrm{l}$ dan F. 1,25 $\mathrm{ml} / \mathrm{l}$ dapat mengakibatkan resistensi tertinggi yaitu 3,44 \% terhadap insektisida kimia Brantas 25 EC.

\section{DAFTAR PUSTAKA}

[1] Arifin, M., Yusmani, dan P., D., K. (2010). Insektisida Biorasional Untuk Mengendalikan Hama Kepik Coklat (Riptortus Linearis) Pada Kedelai Prosiding Seminar Hasil Penelitian Tanaman Aneka Kacang Dan Umbi 2010. Balai Penelitian Tanaman Aneka Kacang Dan Umbi: 233-245

[2] Amalia, E., R. Agus, M., H., Puji, L., dan Purnomo. (2017). Uji mortalitas penghisap polong kedelai ( $R$. linearis) (Hemiptera : Alydidae) setelah aplikasi ekstrak daun papaya, babadotan dan mimba di Laboratorium. Jurnal Agrotek Tropika. 5(1):46-50

[3] Baehaki, S.E,E.H. Iswanto, dan D. Munawar. Resistensi wereng coklat terhadap insektisida yang beredar di sentra produksi padi. Jurnal Penelitian Pertanian Tanaman Pangan. 34(2).

[4] Bayu, Ayda., K. dan M. Muchlish Adie (2017). Respon Genotipe kedelai biji besar dan umur ganjah terhadap kompleks hama pengisap polong. Jurnal HPT Tropika. 17(2):128-136

[5] Capinera, J.L. 2001 Green Peach Aphid, Myzus Persicae (Sulzer) (Insecta: Hemiptera: Apididae) and Capsicum annuum (Solanaceae) volatiles: Their Effect on Predators Attraction. Bol. San. Veg. Plagas 31:503-507

[6] Dirjen Tanaman Pangan. (2014). Laporan Tahunan Direktorat Tanaman Pangan 2013. Kementerian Pertanian RI Direktorat Jenderal Tanaman Pangan. Jakarta.

[7] Inani S. (2007). Korelasi beberapa karakter kuantitatif terhadap serangan hama aphid (Aphis craccivora Koch.) pada tanaman kacang panjang (Vigna sesquipedalis L. Fruwirth) Tesis. Malang: Fakultas Pertanian, Universitas Brawijaya.

[8] Marwoto. (2006). Status hama pengisap polong kedelai $R$. linearis dan cara pengendalianya. Jurnal Proteksi balai penelitian tanaman kacang kacangan, dan umbi-umbian. 12:69-74

[9] Marwoto, Suharsono dan Supriyatin. (2006). Hama Kedelai dan Komponen Alternatif dalam Pengen-dalian Hama Terpadu. Monograf. Balitkabi No 4.

[10] Marida, S., Y., I., B., Ayda, K., dan Muchlish, M. Adie. (2017) Respon genotype kedelai biji dan umur genja terhadap kompleks hama pengisap polong. Jurnal HPT Tropika.17(2):128136.

[11] Mawan, A. Dan Amalia, H. (2011). Statistika Demografi Riptortus linearis F. (Hemiptera:Alydidae) pada kacang panjang (Vigna sinensis L.). Jurnal Entomologi Indonesia (8):8-16.

[12] Meilin, A. dan Nasamsir. (2016) Serangga dan perakarannya dalam bidang pertanian dan kehidupan. Jurnal Media Pertanian.1(1) :18-28.

[13] Prayogo, Y. (2009). Kajian Cendawan Entomopatogen Lecani cillium (Verticillium) lecanii (Zimm.) (Viegas) Zare dan Gams sebagai Agens Hayati untuk Mengendalikan Telur Hama Penghisap Polong Kedelai Riptortus linearis (F.) (Hemiptera: Alydidae). (Disertasi). Sekolah Pasca sarjana, Departemen Proteksi Tanaman, Institut Pertanian Bogor.

[14] Prayogo,Y., dan Suharsono. (2005). Optimalisas I Pengendalian Hama Pengisap Polong Kedelai (Riptortus linearis) dengan Cendawan Entomopatogen Verticillium lecanii. Jurnal Litbang Pertanian, 24(4): 123-130

[15] Puspitasari dan Marendra (2006), Perilaku petani dalam menggunakan pestisida di sentra produksi bawang merah. Proseding Seminar Nasional Spesifik Lokasi untuk mendapatkan ketahanan pangan pada era Masyarakat ekonomi ASEAN bandar lampung. 2(8) :2685-2233. Masalah tahun

[16] Ratna Y., Y. Andi Trisyono, Kasumbogo Untung, Didik Indradewa (2009) Resurjensi Serangga Hama Karena Perubahan Fisiologi Tanaman Dan Serangga Sasaran Setelah Aplikasi Insektisida. Jurnal Perlindungan Tanaman Indonesia 15(2):55-64

[17] Selvia, K., A, R., dan Setyono (2015) Efektifikasi Pupuk Kalium Organik Cair Tahapan pemupukan kalium Terhadap Pertumbuhan, Produksi, dan Daya Simpan Kacang Panjang (Vigna sesquipedalis (L.) Fruhw.) Jurnal Agronida 1(2) : 92-105

[18] Sulistinah, N., S., Antonius, M., dan Rahmansyah. (2011). Pengaruh Residu Pestisida Pola Populasi Bakteri dan Fungi Tanah di Rumah kaca. Jurnal Teknologi Lingkungan. 12(1): 43-53.

[19] Tengkano, W., Arifin, M., dan Tohir, A., M. (1992).Bioekologi, serangan dan pengendalian hama pengisap dan penggerek polongkedelai. Dalam 
Marwoto, Saleh, N.,Sunardi dan Winarto, A. (Ed.). Risalah Lokakarya Pengendalian HamaTerpadu Tanaman Kedelai, Malang8-10 Agustus (1991). Balai Penelitian.

[20] Warsi, R., A. I., W., L. S, dan Sudakir Efektifitas insektisida Lamda Sihalotrin 25 EC dan Suflutrin 50 EC terhadap pengisap buah jarak pagar (Chrysochoris javanus) di pakuwon sukabumi jawa barat. Jurnal Evikasi insektisida lamda sihalotrin 25 EC dan siflutrin 50 EC terhadap pengisap buah jarak pagar. 1(3).

[21] Venugopal, N., V., S., B. Sumalatha., S. R., Bonthula., dan G, Veeribabu. (2012). Spectrophotometric Determination of Organophosphate Insecticide (Chlorpyrifos) Based on Diazotisation With Anthranilic Acid. The Malaysian Journal of Analytical Sciences16(2):180186.

[22] Wahyu, G., A., S dan Adie, M., M. (2008). Penciri Ketahanan Morfologi Genotipe Kedelai terhadap Hama Penggerek Polong. Jurnal PenelitianPertanian Tanaman Pangan. 27(2): 95-100.

[23] Zote, V., K., Munj, A., Y., Salvi, S., P., dan Haldavnekar, P. C.(2017). Efficacy of newer insecticides against tea mosquito bug in cashew Helopeltis antonii sign inKonkan Region of Maharashtra. International Journal of Chemical Studies, 5(4): 713-715.

[24] Zaevie, B., Napitupulu, M., dan Astuti, P. (2014), Respon Tanaman Kacang Panjang (Vigna sinensis L.) terhadap pemberian pupuk NPK Pelangi dan Pupuk Organik Cair Nasa, Jurnal Agrifor, 13(1): 1412-6885. 